\title{
A OPOSIÇÃO À ATUAÇÃO BRASILEIRA NO PARAGUAI PÓS- GUERRA DA TRÍPLICE ALIANÇA: O CASO DO JORNAL LA VOZ DEL PUEBLO (1870)
}

\author{
THE OPPOSITION TO BRAZILIAN PERFORMANCE IN PARAGUAY \\ POST WAR OF TRIPLE ALLIENCE: THE CASE OF THE \\ NEWSPAPER LA VOZ DEL PUEBLO (1870)
}

DOI: http//dx.doi.org/10.15448/2178-3748.2017.1.22871

\author{
Bruno Félix Segatto \\ Mestre em História (UFRGS) \\ Professor na rede privada de ensino de Porto Alegre \\ bf.segatto@gmail.com
}

\begin{abstract}
RESUMO: Em março de 1870, o presidente paraguaio Francisco Solano Lopez foi assassinado por tropas brasileiras em Cerro Corá, norte do Paraguai. Este episódio marcou o término da guerra entre a Tríplice Aliança (Brasil, Argentina e Uruguai) e o Paraguai. A partir de então, o país derrotado ficou ocupado política e militarmente por tropas aliadas até 1876 , sendo este período marcado pela desorganização política e social daquela nação. Durante os anos 1869 e 1870, enquanto estava em questão o caráter da Constituição que iria reger o país no futuro, surgiram, em Assunção, os primeiros jornais independentes, os quais deram início à imprensa privada paraguaia. Um destes jornais foi La Voz del Pueblo, órgão representante do Club del Pueblo, próArgentina e que assumiu uma postura crítica em relação à atuação das autoridades civis e militares brasileiras em solo guarani. Este artigo objetiva analisar a atuação do referido jornal no conturbado momento político em que circulou, durante os meses de março a setembro de 1870. Embora tenha circulado durante um curto período, este jornal constitui importante fonte histórica para o estudo do Paraguai nos meses que se sucederam à morte de Solano Lopez e antecederam a aprovação da Constituição Nacional, em novembro de 1870.
\end{abstract}

PALAVRAS-CHAVE: Imprensa, Pós-Guerra da Tríplice Aliança, La Voz del Pueblo.

ABSTRACT: In March 1870, Paraguay's President Francisco Solano Lopez was assassinated by Brazilian troops in Cerro Corá, northern Paraguay. This episode marked the end of the war between the Triple Allience (Brazil, Argentina, Uruguay) against Paraguay. From then on, the defeated country became politically and militarily occupied by Allied troops until 1876. This period was marked by political and social disorder. During 1869 and 1870 - while was in issue the character of the Constitution that would rule the country in the future- the first independent newspapers appeared in Asunción, which has begun private Paraguayan press. One of those newspapers was La Voz del Pueblo: representative body of Club del Pueblo, pro-Argentina that adopted a critical position in relation to civil and military authorities in Guarani's land. This article aims to analyse the performance of the mentioned newspaper during the turbulent political moment in which circulated, between March and September 1870. Although it circulated during a brief period, this newspaper constitute an important historical source to the study of Paraguy in the months which succeeded the death of Solano Lopez and anteceded the approval of the National Constitution, in November 1870.

KEYWORDS: Press, Post War of Triple Aliance, La Voz del Pueblo. 


\section{Introdução}

Após quatro anos de guerra entre a Tríplice Aliança (Brasil, Argentina e Uruguai) e o Paraguai de Solano Lopez, em janeiro de 1869, tropas aliadas ocuparam a capital Assunção e deram, assim, início à ocupação político-militar daquele país. Em agosto, sob supervisão das autoridades aliadas no país, foi instalado um Governo Provisório paraguaio com a eleição de um Triunvirato integrado por Carlos Loizaga, José Diaz de Bedoya e Cirilo Antonio Rivarola.

O término definitivo do conflito ocorreu em março de 1870, quando o presidente paraguaio foi assassinado por tropas brasileiras em Cerro Corá, norte do Paraguai. A morte de Lopez abriu caminho para a reorganização política do país, pois a partir de então se passou a organizar a eleição de deputados para a Assembleia Constituinte, que ficaria encarregada de elaborar a primeira Constituição paraguaia ${ }^{1}$. Após as eleições, ocorridas em julho, as sessões tiveram início em agosto e foram concluídas com o juramento da Carta em novembro².

Os meses transcorridos entre a ocupação da capital, em janeiro de 1869, e o juramento da Constituição, em novembro do ano seguinte, foram marcados por intensas disputas políticas entre as facções locais e pela condição de miséria e prostração da maioria da população guarani sobrevivente (WHIGHAM, 2015). Apesar da situação em que se encontrava durante este período o país, sobretudo a capital Assunção, viu nascer os primeiros periódicos privados paraguaios: La Regeneración, El Paraguay e La Voz del Pueblo, os quais inauguraram a prática dos debates públicos através da imprensa livre, algo inédito até então.

Os estudos sobre a imprensa platina no século XIX passaram por importantes transformações nos últimos anos. Na Argentina, Fabio Wasserman (2013) ressaltou a necessidade de superar as interpretações que viam a imprensa como um mero suporte de informações ou representações e propôs considerá-la como uma "práctica productora de sentido y como um actor social y político" (2013, p. 2). No Brasil, Marialva Barbosa (2010) surge como importante referência ao propor uma história social e cultural da comunicação impressa. Conforme a autora, a imprensa produz:

textos que falam de seu cotidiano e outros que deixam pistas sobre as suas relações com as instâncias de poder. Por trás das letras impressas, das fotos e ilustrações publicadas, é possível remontar todo o circuito da comunicação: o que eram essas publicações, quem escrevia nesses jornais, para quem se

\footnotetext{
${ }^{1}$ A Constituição de 1870 foi a primeira a vigorar no país, pois até então as leis estabelecidas pelo Congresso não especificavam as garantias dos cidadãos nem definia com clareza as funções do Estado (ARECES, 2011).

${ }^{2}$ A Constituição de 1870 se encontra disponível no site do Tribunal Superior de Justiça Eleitoral daquele país: http://www.tsje.gov.py/constituciones.php
} 
escrevia e, sobretudo, quem escrevia nesses jornais, para quem se escrevia... (BARBOSA, 2010, p. 11).

Antes de 1869, os jornais que circularam no Paraguai tinham o caráter de oficial, uma vez que estavam diretamente ligados aos presidentes Carlos Antonio (1844-1862) e Francisco Solano Lopez (1862-1870). Em referência aos jornais que circularam durante a presidência de Carlos Antonio Lopez, Juan Crichigno (2010, p. 20) afirma que "losperiodicos de Lopez carecían de opinión, debate y polémica o discusión. Se limitaban a informar y a fijar el ordenamiento de la vida ciudadana". Na década de 1860, durante a guerra com a Tríplice Aliança, surgiram os periodicos de trinchera que marcariam a história da imprensa paraguaia por sua singularidade. El Centinela, Cabichuí, Cacique Lambaré e La Estrella constituíam o que Ticio Escobar designa "imprensa combativa", uma vez que foram usados como instrumentos de moralização, propaganda e doutrinação (ESCOBAR, 1995, p. 123).

A imprensa surgida durante os primeiros meses de ocupação político-militar de Assunção estava diretamente vinculada à política local: La Regeneración e El Paraguay eram os órgãos difusores do liberal Gran Club del Pueblo, enquanto La Voz del Pueblo era do grupo bareirista Club del Pueblo. Eram os primeiros periódicos privados surgidos no país, tendo em vista que até então somente haviam circulado jornais oficiais que eram redigidos e impressos em estabelecimentos dos governos López, os quais não permitiam a atuação de imprensa de oposição no país (CRICHGNO, 2010, p. 29).

Embora tenham surgido em um contexto de maior liberdade de atuação para a imprensa, Harris Warren assinala que fundar e manter um periódico no país durante a ocupação era tarefa difícil: "La libertad de prensa fue un ideal no realizado em los gobiernos de posguerra, que cerraban periodicos de oposición discrecionalmente. La falta de tolerância con la crítica periodística fue la actitud prevaleciente de casi toda la historia paraguaya..." (WARREN, 2009, p. 240).

Considerando que a imprensa no século XIX constituía "el vehículo de proyectos, el instrumento de debate, el propulsor de valores, uno de los principales medios de hacer política, de reproducir y constituir imágenes de la sociedad" (ALONSO, 2003, p. 10), este artigo tem como objetivo analisar a atuação de um destes jornais, La Voz del Pueblo, em relação à política brasileira no Paraguai durante os meses em que circulou, de março a setembro de 1870. Uma vez que um jornal possui uma existência relacional, ou seja, em relação com outros jornais contemporâneos com os quais dialoga e polemiza, para realizar esta análise também foram consultados outros jornais paraguaios, como La Regeneración e El Paraguay, e os argentinos El Nacional e La Tribuna. 
Fator que dificultou a pesquisa foi a pequena quantidade de números do periódico em questão encontrados ${ }^{3}$, o que tornou propício o uso do paradigma indiciário proposto por Carlo Ginzburg (2012, p. 157), que se refere aos "sinais" e “indícios” pelos quais a realidade se dá a decifrar, dando ao conhecimento histórico um caráter indireto, indiciário e conjetural. Reconstituir a atuação do periódico La Voz del Pueblo requereu uma leitura intensiva dos poucos números disponíveis e uma busca por referências ao mesmo nos outros jornais citados.

Embora tenha tido uma existência efêmera, La Voz del Pueblo teve uma intensa atuação política criticando ações de autoridades civis e militares brasileiras no Paraguai, assim como a falta de legitimidade do Governo Provisório, conforme se verá adiante.

\section{Política e imprensa no imediato pós-guerra da Tríplice Aliança}

Passados quatro anos de guerra entre a Tríplice Aliança e o Paraguai, este teve sua capital ocupada nos primeiros dias de 1869, enquanto Solano Lopez seguia resistindo no interior do país. Com a ocupação político-militar de Assunção, um grande número de soldados e autoridades aliadas, soldados e oficiais da Legião Paraguaia ${ }^{4}$, comerciantes, correspondentes diplomáticos e de órgãos de imprensa e centenas de paraguaios que estavam no interior ou exilados no exterior retornaram ao país ${ }^{5}$. A capital, que se encontrava abandonada no momento em que as tropas aliadas a invadiram, chegou a contar com 17 mil habitantes ainda em 1869 (WARREN, 2009, p. 50).

O país como um todo constituía um cenário de desolação. Sua população, que em 1865 era de aproximadamente 500 mil habitantes, em 1870 havia sido reduzida a metade (BREZZO, 2011, p. 200). Cidades, plantações e estradas estavam destruídas e a população sobrevivente perambulava rumo à capital, onde engrossava o número de esfomeados que mendigavam alimentos aos soldados aliados (WHIGHAM, 2015, p. 1097).

A situação em que se encontrava o país derrotado colocava as autoridades do Império brasileiro em alerta, pois temiam que esta debilidade poderia levar à incorporação, voluntária ou não, à Argentina. Desde a ocupação de Assunção até a retirada das tropas em 1876, a ação do Império no Paraguai se orientou a evitar que políticos considerados "argentinistas"

\footnotetext{
${ }^{3}$ Foram encontrados somente três números do jornal La Voz del Pueblo no acervo do Instituto HistóricoGeográfico do Rio Grande do Sul (IHGRS). Esses números são os dos dias 19 de maio (n. 24), 14 de julho (n. 46) e 19 de julho (n. 48) de 1870.

${ }^{4}$ A Legião Paraguaia era uma força militar composta por paraguaios opositores aos governos Lopez, que integraram o Exército Argentino contra as tropas guaranis (ESTEVES, 1996).

${ }^{5}$ A respeito da história paraguaia pós-1870, ver: ACOSTA TOLEDO (2013), BREZZO (2011), BREZZO e FIGALLO (1999), ROLÓN (2011), WARREN (2009) e WHIGHAM (2012).
} 
ocupassem cargos públicos importantes na administração do Estado que estava por reestruturar-se (DORATIOTO, 2004, p. 210).

A principal autoridade civil que o Império possuía no Paraguai era o Conselheiro José Maria da Silva Paranhos, a quem foi encarregada a missão de instalar um Governo Provisório paraguaio ainda em 1869, ou seja, enquanto Solano Lopez seguia resistindo no interior do país. A instalação do Governo Provisório constituía uma medida que o Império adotou acreditando garantir a existência do Paraguai como Estado independente (DORATIOTO, 2014, p. 48). No entanto, o estabelecimento deste governo não se deu sem complicações, o que levou o Conselheiro imperial a intervir nas questões políticas internas do país (WHIGHAM, 2015, p. 1090). A pressão e influência brasileira sobre as autoridades paraguaias era tanta que entre 1869 e 1874 "el Paraguay fue prácticamente um protectorado del Imperio" (BARATTA, 2015, p. 30).

As dificuldades encontradas por Paranhos diziam respeito à divisão ocorrida entre os membros do que se poderia definir como "elite política" paraguaia. Durante os meses que se seguiram à ocupação aliada, em meio aos debates e às negociações para a constituição do Governo Provisório, surgiram duas facções políticas que criaram os primeiros clubes, orientados à disputa eleitoral por vir. Embora invocassem metas ideológicas, estas facções atuavam como se os ressentimentos privados fossem mais importantes, sendo o personalismo e o faccionalismo características marcantes de ambos os grupos (WHIGHAM, 2012; WHIGHAM, 2015).

De um lado, aglutinou-se ao redor da família Decoud um considerável número de jovens paraguaios que haviam estado exilados durante os governos Lopez, em sua maioria na Argentina. A maioria destes paraguaios integrou a Legião Paraguaia quando do ingresso da Argentina na guerra em 1865. Após o término do conflito, esta facção criou o Club del Pueblo e, em outubro de 1869, fundou o primeiro jornal independente no país, o La Regeneración. Em março de 1870, com o início do processo eleitoral aberto com a morte de Solano Lopez, passou a chamar-se Gran Club del Pueblo e tinha Facundo Machain como seu presidente. Conforme Thomas Whigham (2012, p. 404), esta facção “profesaba la orientación más "liberal" entre las incipientes organizaciones políticas paraguayas".

Por outro lado, formou-se uma facção mais heterogênea, pois a integravam indivíduos que haviam sido funcionários de Solano Lopez, assim como alguns ex-membros da Legião Paraguaia e jovens paraguaios que não simpatizavam com a família Decoud; todos reunidos em torno a Cándido Bareiro, ex-representante de Solano Lopez na Europa. Este grupo constituía a "contraparte "conservadora" de los decoudistas" (WHIGHAM, 2012, p. 405). 
Pregando a união entre os paraguaios, esta facção fundou o Club Unión Republicana, mas alterou seu nome em março de 1870 para Club del Pueblo, mesmo mês em que fundou o seu órgão represente, o periódico La Voz del Pueblo.

La Voz del Pueblo veio a público em março de 1870 graças à atuação de alguns cidadãos paraguaios e argentinos, inconformados com a influência brasileira no Paraguai e críticos ao jornal decoudista que se encontrava em circulação desde outubro de 1869, o La Regeneración (WARREN, 2009, p. 243). Tinha o argentino Miguel Gallegos como redator e editor responsável, Florencio Fredes como diretor da parte tipográfica e o também argentino Miguel Macias, o espanhol Victorino Abente y Lago e o paraguaio Sotero Cayo Miltos como colaboradores. A assinatura mensal (suscrición) custava dois pesos bolivianos e o número suelto dois reais bolivianos. Além da suscrición, contava com ingressos provenientes da publicação de avisos publicitários e, em algumas ocasiões, de documentos e decretos oficiais. Vinha a público nas terças, quintas e sábados e estava composto pelas seguintes seções: Almanaque, Correspondencia, editorial, Folletín, Colaboración, Mesa Revuelta e Miscelanea.

La Voz del Pueblo apresenta inúmeras características em comum com os demais periódicos platinos e brasileiros que circularam durante a década de 1870, como a condição profissional incipiente dos seus redatores. Se no Brasil e na Argentina a profissão de jornalista estava em vias de profissionalização (DE MARCO, 2006; BARBOSA, 2010), no Paraguai ela estava recém iniciando, posto que antes não havia existido imprensa livre no país. Os redatores dos jornais existentes naquele momento, Miguel Gallegos por parte de La Voz del Pueblo, e os irmãos Juan José e José Segundo Decoud por parte de La Regeneración, também se dedicavam a outras atividades profissionais e/ou políticas: o primeiro além de membro do Club Unión e posterior Club del Pueblo, era cirurgião no Hospital Argentino, enquanto os segundos eram deputados convencionais e importantes líderes do Gran Club del Pueblo. O mesmo ocorria com os colaboradores de ambos os jornais. Nesse sentido, resulta pertinente a proposição de Fabio Wasserman (2013, p. 9) de definir estes indivíduos como "publicistas", aqueles que "por su formación o profesión tenían la capacidad de hacer uso de la palabra escrita y la utilizaban para dar a conocer sus ideas o sentar posiciones sobre temas que pudieran ser de interés público".

A associação que se estabelece entre La Voz del Pueblo e os demais jornais paraguaios e argentinos se explica pela existência de um "circuito da informação" (DARNTON, 1990) que conectava os estabelecimentos onde funcionavam (as oficinas), as casas dos seus assinantes, os estabelecimentos públicos como os parlamentos e as residências oficiais, as ruas, os cafés, os portos e os navios que faziam a rota Assunção-Buenos Aires passando por 
cidades portuárias como Corrientes, Paraná e Rosario ${ }^{6}$. Deste modo, os jornais paraguaios circulavam pelas redações de jornais argentinos e despertavam a simpatia ou a oposição dos seus pares:

La prensa Argentina también se ajita apoyando decididamente la causa del pueblo paraguayo, y adhiriéndose al pensamiento que nos ha guiado desde mucho tiempo; la sociedad porteña por medio de la amistad particular nos envía palabras de felicitación por la ardua pero hermosa tarea que se ha impuesto "La Voz del Pueblo" de sostener la independencia de este país amenazado por la estupidez de un mandón que se [ilegível] decididamente a la funesta política de un hombre que tiende sus redes al pueblo paraguayo. (La Voz del Pueblo, Assunção, 14/07/1870).

É justamente esta inserção de LaVoz del Pueblo neste circuito de informações que interligava os jornais platinos que auxiliou na reconstituição da atuação dos responsáveis pelo periódico, pois, como se verá adiante, alguns jornais argentinos reproduziram textos publicados pelo periódico paraguaio ou os comentaram de modo a referenciá-lo.

Outro aspecto em comum com os demais jornais platinos e brasileiros é a existência efêmera, pois circulou por somente sete meses. Inúmeros eram os motivos que levavam os proprietários e editores a fecharem as portas de suas oficinas: dificuldades financeiras, conflitos entre os redatores e/ou proprietários, perseguições perpetradas pelos governos ou até mesmo a destruição da máquina impressora em ataques violentos, como foi o caso tanto de $L a$ Voz del Pueblo como do seu opositor La Regeneración. Ambos os jornais deixaram de circular em setembro de 1870 por causa de violentos ataques aos seus estabelecimentos realizados por agentes desconhecidos (WHIGHAM, 2015, p. 1115).

Este violento episódio, somado a outros que os redatores e colaboradores de $\mathrm{La} \mathrm{Voz}$ del Pueblo denunciaram durante os meses em que circulou, evidenciam o quão instável e precária eram as condições de atuação dos publicistas paraguaios nos meses que antecederam o juramento da Constituição, em novembro de 1870. Embora não se tenha informações a respeito deste ataque, não seria exagero supor que o ocorrido tenha estado relacionado à intensa campanha realizada, através do jornal, contra a atuação brasileira no Paraguai, conforme se verá adiante.

\footnotetext{
${ }^{6}$ Os anúncios da seção Marítima de El Nacional e La Tribuna mostram que os barcos Venecia, Río de la Plata, Cuyaba, Gualeguay, 34-Victoria-34, Goya, Taragui e Guarani faziam o percurso Buenos Aires-Assunção.
} 


\section{La Voz del Pueblo: um jornal argentinista em defesa do povo paraguaio}

A notícia do surgimento de um novo períodico na capital paraguaia despertou a expectativa de seus habitantes, principalmente dos redatores do opositor e até então único jornal, La Regeneración: "Se nos dice que el Gobierno Provisorio ha dado el permiso para que um nuevo periódico se establezca en esta ciudad. Felicitamos sinceramente a los miembros del Triunvirato por un acto que les honra altamente..." (La Regeneración, Assunção, 02/02/1870). No entanto, a aparição do novo jornal ocorreria somente em fins de março, o que aumentava ainda mais a expectativa dos irmãos Juan e José Segundo Decoud: "Mucho tarda en aparecer el nuevo colega que según se nos ha dicho se llamará "La Unión” y según otros "La Voz del Pueblo". Sea como quiera, esperamos que será un nuevo campeón de las libertades públicas, si quiere cobrar crédito y popularidad" (La Regeneración, Assunção, 09/03/1870).

Estas duas pequenas citações evidenciam, por um lado, uma condição necessária para o surgimento de um jornal naqueles meses: a aprovação do Governo Provisório e, embora não faça referência, do Conselheiro José Maria Paranhos, pois “ningún periódico podia sobrevivir sin el consentimiento brasilero, y varias casas editoras sufrieron los ataques violentos de los brasileros o sus esbirros" (WARREN, 2009, p. 240). Por outro lado, as expressões "Se nos dice" e "según se nos ha dicho" evidenciam que as marcas de oralidade eram uma constante nos textos dos jornais paraguaios, reforçando a afirmação de Marialva Barbosa (2010, p. 30) de que o "mundo oral está inscrito na maioria das informações impressas no século XIX". Conforme a autora,

As conversas ao pé do ouvido e as informações passadas de uns para os outros são também fontes privilegiadas de informação. Pessoas vindas de províncias distantes ou de países longínquos fazem "correr notícias" ou "correr vozes" de tal forma que possibilitam a transformação do mundo oral em letras impressas. (BARBOSA, 2010, p. 30).

Durante as semanas que antecederam a aparição do novo jornal, corriam os rumores a respeito do nome que teria e, após ter-se a sua confirmação, os boatos passaram a dizer respeito à postura política que o futuro periódico assumiria:

Ayer se repartió por las calles un cartelito anunciando la próxima aparición del nuevo periódico, que se llamará "La Voz del Pueblo". Es opinión general en el público que va a empezar una fuerte propaganda de oposición, no sabemos si al Gobierno ó a los Aliados, ó alguna de las tres naciones aliadas. Ya veremos. (La Regeneración, Assunção, 13/03/1870). 
O questionamento quanto à posição política do jornal, antes mesmo de sua aparição, não resulta surpreendente em um contexto onde imprensa e política estavam diretamente relacionadas. O surgimento de La Voz del Pueblo ocorreu em função da disputa política que existia entre as duas facções paraguaias, o decoudista Gran Club del Pueblo e o bareirista Club del Pueblo (ex-ClubUnión).

O Conselheiro José Maria da Silva Paranhos conseguiu impedir, com sua influência e pressão, que Juan Francisco Decoud assumisse um dos três cargos do Triunvirato que integrou o Governo Provisório paraguaio. No entanto, em troca aceitou ceder cargos de segundo escalão na administração daquele governo aos membros do clube decoudista, tais como o próprio Juan Francisco e seu filho José Segundo, Facundo Machaín e Jaime Sosa, nomeados Chefe de Polícia, Secretário de Governo, Juiz e Inspetor de Escolas, respectivamente (ESTEVES, 1996). O Gran Club del Pueblo, portanto, foi beneficiado na distribuição dos cargos na administração pública em detrimento do opositor e bareirista Club del Pueblo.

À facção de CándidoBareiro coube, deste modo, fazer oposição ao Governo Provisório e ao Gran Club del Pueblo; porém, não contava com um órgão difusor que o representasse, algo que o grupo decoudista já possuía desde outubro de 1869 (CRICHIGNO, 2010, p. 52; WARREN, 2009, p. 243). Além de oposicionista aos dois anteriores, o clube bareirista também fundou La Voz del Pueblo com o objetivo de contrapor a influência brasileira no Paraguai, pois considerava que tanto os triúnviros do Governo Provisório como os membros do Gran Club eram coniventes com a pressão exercida pelas autoridades do Império.

\begin{abstract}
Nosotros no tomamos un puesto en las columnas de "La Voz del Pueblo" para atentar contra los intereses paraguayos, y prohijar los argentinos con mengua de los primeros; nosotros subimos a la prensa para ayudar con nuestro pobre contingente a centralizar, diré así, los diferentes grupos del pueblo paraguayo que vagaban a merced de un circulo esclusivo; nosotros queremos ensanchar la acción de ese círculo y dar cabida a los repelidos. ( $L a$ Voz del Pueblo, Assunção, 14/07/1870).
\end{abstract}

Percebe-se, neste texto de colaboração assinado pelo pseudônimo Saicam, a preocupação em assinalar que embora La Voz del Pueblo fosse um jornal "argentinista" isso não significaria que não defenderia os interesses do povo paraguaio, o qual, na sua visão, estaria vagando a mercê de um "círculo exclusivo", uma referência aos integrantes do rival Gran Club. 
Apesar de pertencer ao clube de Cándido Bareiro, a aparição de $L a$ Voz foi saudada com cordiais palavras pelos redatores de La Regeneración, embora estes já alertassem para possíveis conflitos no futuro:

\begin{abstract}
Ayer apareció el segundo numero de este colega, trayendo entre otros artículos uno que se ocupa de la actitud del pueblo paraguayo para las futuras elecciones; a pesar de estar muy bien escrito no estamos conforme con algunas de sus apreciaciones. Por lo demás nuestro colega se ha presentado en la palestra lleno de altura y dignidad, sin enlodarse en personalidades que son tan odiosas como repugnantes. [...] Pero los elementos heterogéneos que han dado vida a nuestro colega, nos hace presentir [ilegível] próxima campaña electoral y una propaganda más exaltada de lo conveniente. (La Regeneración, Assunção, 27/03/1870).
\end{abstract}

De fato, as trocas de acusações entre os redatores e colaboradores dos dois periódicos já assumiram tons elevados no mês seguinte, como se percebe no artigo de Juan Silvano Godoy, colaborador de La Regeneración:

La misión del periódico La Voz del Pueblo ha sido conocida. Ese periódico dirigido en su mayor parte por hombres agenos a las desgracias de nuestra patria asalareados quizás por algún ex - agente del tirano, no lleva otro objeto que procurar a todo trance introducir la cizaña de la discordia, la división entre los paraguayos que han sobrevivido a la gran catástrofe, haciendo uso para esto de cuantos medios esté a su alcance... ( $L a$ Regeneración, Assunção, 06/04/1870).

Ao referenciar-se a "hombresagenos a las desgracias de nuestra pátria", Godoy enfatiza a condição de estrangeiro do redator e de alguns colaboradores de La Voz del Pueblo e ainda os acusa de serem pagos por Cándido Bareiro, ex-agente de Lopez na Europa, para provocar a divisão entre os paraguaios.

A elite política paraguaia se encontrava, de fato, dividida. No entanto, esta divisão não ocorria por questões ideológicas, mas sim pelo personalismo imperante. Conforme Thomas Whigham:

\footnotetext{
"Estas asociaciones [clubes políticos] invocaban metas ideológicas, pero actuaban como si los resentimientos privados fueran lo más importante. Los asunceños entendieron esto desde el principio y tendieron a calificar las facciones en términos personalistas, como grupos de encumbrados hombres locales, sus familias y criados" (WHIGHAM, 2012 p. 403).
}

Enquanto os membros do Gran Club sustentavam Cirilo Rivarola para a presidência do Paraguai, os integrantes do Club del Pueblo militavam pelo seu líder, Cándido Bareiro, nos seguintes termos: 
Bareiro para nosotros no representa un hombre, ostenta su prestijio la voluntad del pueblo paraguayo. ¿No merece ese puesto? Si, lo merece; yo soy franco y no temo la censura por acre q' sea. En Bareiro he observado las cualidades que constituyen al buen gobernante; le he seguido con afán en todas sus fases como hombre político y he encontrado el hombre aparente para la situación. Prestijio entre nacionales y extranjeros, altura en las cuestiones, amante de su patria, pues desea verla independiente; firme en sus procederes, valor cívico; conocimientos en los negocios públicos, y amante del progreso. Esas son las cualidades mas resaltantes que forman el carácter de Bareiro, y es por eso que hemos acatado su candidatura que abiertamente la proclama el pueblo. (La Voz del Pueblo, Assunção, 14/07/1870).

Ambas as facções pregavam preceitos liberais e a imigração europeia, por exemplo, como medidas necessárias para a reconstrução do país. Os membros do decoudista Gran Club, que se auto identificavam enquanto jovens liberais e ilustrados, fizeram intensa propaganda por meio de seus jornais La Regeneración e El Paraguay em defesa da regeneração do país por meio da instrução pública e da imigração, assim como a sanção de uma Constituição de caráter liberal que regulasse as atribuições dos três poderes do Estado. Os membros do bareirista Club del Pueblo, por sua vez, não se diferenciavam muito dos seus opositores, pelo menos na sua prédica discursiva, como pode-se depreender do Programa de La Voz del Pueblo reproduzido pelo jornal portenho La Tribuna:

Aceptado por el Exmo. Gobierno Provisorio - y que la Voz del Pueblo levanta como bandera de su propaganda. Respetar fielmente los propósitos de la alianza manifestados en sus tratados públicos. Unión y fraternidad entre nacionales y estrangeros, entre ambos y el Gobierno. Hacer que el Paraguay sea para todos, y que leyes liberales y protectoras sean el amparo de todo aquel que busca en el país por medio de su honrado trabajo la adquisición de una posición. Dejar que las ideas se manifiesten con libertad siempre que su propaganda no sea desquicio. Olvidar lo pasado; y con empeño y fe, buscar en el porvenir la reconstrucción del país. Ser el eco de los intereses comerciales por ser el comercio la vida de las naciones. En fin, levantar bien alto la bandera de la nacionalidad paraguaya, para que á su sombra se elabore el engrandecimiento del país (La Tribuna, Buenos Aires, 01/04/1870).

Os decoudistas, por seu turno, tratavam de desqualificar o liberalismo da facção de Barreiro, como se percebe no seguinte excerto de El Paraguay, jornal subsidiário de La Regeneración que circulou de maio a junho de 1870 :

Decir a voces para que puedan creer los necios, que "La Voz del Pueblo" hace una propaganda liberal; que se ocupa de los intereses vitales del país; que ilustra y enseña al pueblo en su marcha republicana; que predican la unión, la paz, la fraternidad a todos los paraguayos, y en seguida insitarlos a la revuelta, a la rebelión, aconsejándolos al desconocimiento de la autoridad 
nacional; no es a fe de caballero una acción infame digna solo de hombres sin dignidad ni honra? (El Paraguay, Assunção, 28/05/1870).

Embora também se apresentassem como defensores do liberalismo, Harris Warren (2009, p. 72) destaca que os membros da facção de Cándido Bareiro desconfiavam dos jovens intelectuais e ilustrados da facção decoudista e que acreditavam que a política era "el arte de lo militarmente posible". Por esta consideração, pela heterogeneidade de sua composição e pelo fato de seus membros terem aceitado fazer parte do Governo Provisório em setembro de 1870, como se verá adiante, não é exagero considerar que a facção de Cándido Bareiro, mais do que liberal, constituía uma agrupação política de caráter pragmático e oportunista.

No entanto, se a atuação dos redatores e colaboradores de La Voz del Pueblo se destacou e se diferenciou em algo, foi na crítica à atuação das autoridades civis e militares brasileiras no Paraguai, conforme se verá adiante.

\section{“Toda nuestra oposición es ála política del Consejero Paranhos...": a oposição à atuação do Brasil no Paraguai}

Cándido Bareiro e seu grupo já haviam tentado derrubar o Governo Provisório paraguaio no início de 1870 , no entanto a tentativa foi frustrada devido ao apoio que as autoridades aliadas prometeram dar ao principal triúnviro paraguaio, Cirilo Rivarola (DORATIOTO, 2004, p. 212). Após o surgimento de La Voz del Pueblo, seus redatores e colaboradores mudaram de estratégia e passaram a disparar críticas à atuação brasileira no Paraguai. No entanto, seu redator enfatizava:

\footnotetext{
Nosotros no somos enemigos del Brasil, y aun cuando nos disguste aquella forma de Gobierno, no por eso dejamos de conocer que mientras viva el monarca D. Pedro II, el Brasil será una monarquía tolerable. No somos pues enemigos del Brasil, y como el diplomático Brasilero no es la nación Brasilera, declaramos que somos enemigos de la política Brasilera en el Paraguay, y que no de ahora sino desde la instalación del Gobierno provisorio, venimos combatiéndola, no porque pensamos ser los únicos diplomáticos en el Paraguay, sino porque somos uno de tantos, y porque tenemos el derecho de hacer públicos nuestros pensamientos... ( $\mathrm{La} \mathrm{Voz} \mathrm{del}$ Pueblo, Assunção, 14/07/1870).
}

O principal alvo das investidas de La Voz era o Conselheiro José Maria da Silva Paranhos, a quem consideravam um agente que influenciava, pressionava e interferia na política interna do Paraguai: “Toda nuestra oposición es á la política del Consejero Paranhos, como sería a la del Ministro Argentino si lo viésemos influyendo en lo más mínimo en los 
asuntos locales del Gobierno Provisorio del Paraguay" (La Voz del Pueblo, Assunção, 19/07/1870). E continuava:

Se enoja mucho el diplomático Brasilero, y dice de puerta en puerta que se va al Brasil pues que así lo quiere "La Voz del Pueblo", y se olvida de agregar que hace ya mucho tiempo que debió irse y no volver más hasta no hallarse establecido el Gobierno efectivo con quien se debe tratar, sino porque así lo exijia ningún artículo del tratado, al menos porque así lo exijia la buena y caballeresca política de hacer lo mismo que hacia la República Argentina y la República Oriental, no teniendo aquí ningún ajente diplomático, en misión perpetua, para que no influyera en el réjimen interno del Gobierno Paraguayo, como ha estado influyendo el diplomático Brasilero, y como tiene hoy mismo la idea de influir. ( $\mathrm{Ca}$ Voz del Pueblo, Assunção, 14/07/1870).

As críticas ao Brasil se davam também em relação ao que este Império representava. O Brasil representava o atraso e a barbárie, posto que era uma monarquia escravocrata encravada em um continente repleto de repúblicas que já haviam abolido a escravidão há décadas. Um país que não possuía a mesma afinidade cultural existente entre paraguaios e argentinos, por não compartilharem elementos como a língua e a forma republicana de governo. O redator de $\mathrm{La} \mathrm{Voz} \mathrm{del} \mathrm{Pueblo} \mathrm{questionava} \mathrm{aos} \mathrm{seus} \mathrm{leitores} \mathrm{paraguaios} \mathrm{qual} \mathrm{das}$ influências melhor conviria ao Paraguai nos seguintes termos: "cual os conviene más ¿Qué predomine la influencia Brasilera em vuestra Patria, ó la Argentina? En donde encontrareis más analogía de sistema político; mas afinidad, en el modo de ser de los pueblos?” ( $L a$ Voz del Pueblo, Assunção, 14/07/1870).

Por criticar o Brasil devido ao seu caráter de monarquia escravista atrasada, La Voz del Pueblo fazia parte de um grupo de jornais platinos que condenavam a política brasileira na região do Rio da Prata. Alguns, como La América e El Pueblo de Buenos Aires, assumiram uma postura crítica à aliança com o Brasil e à guerra com o Paraguai desde o início do conflito (BARATTA, 2012). Outros, como El Nacional e La Tribuna da capital, e El Independiente de Corrientes e El Comercio de Entre-Rios, e El Republicano de Entre Ríos assumiram uma postura crítica ao Império no desenrolar da contenda (BARATTA, 2013).

A política brasileira em relação ao Paraguai levantava críticas inclusive entre jornais da Corte. A Reforma e a A República teciam críticas à atuação brasileira naquele país como forma de enfraquecer o gabinete conservador, no caso do primeiro, e inclusive a própria monarquia brasileira, no caso do segundo (DORATIOTO, 1999).

Frente a estas críticas, as autoridades brasileiras afirmavam adotar uma postura de neutralidade frente às questões da política interna paraguaia, o que era rebatido pelos redatores de La Voz: 
Bastante enterados quedamos sobre lo que es la doctrina neutral. Confesamos que antes de hoy no la sabíamos. Ahora cuando veamos marchar un ejército; rodear la casa del Sr. Rivarola con dos Batallones de infantería; otra vez que veamos a una guardia cargar y atacar las armas a la vista de 200 mugeres que están empeñadas en conseguir la libertad de un preso, diremos: hé ahí unos soldados que se preparan a ser neutrales. Bien dicen que mientras más vive uno, mas aprende. Hoy ya sabemos como es la neutralidad del diplomático Brasilero. (La Voz del Pueblo, Assunção, 14/07/1870).

Dado que a facção de Cándido Bareiro se posicionava de forma crítica à atuação brasileira no Paraguai, a oposição ao Governo Provisório surge como uma consequência. Na visão dos bareiristas, o Governo Provisório era necessário, entretanto não era um governo legítimo, pois não havia sido fruto da vontade do povo paraguaio, mas sim dos países aliados, sobretudo o Brasil, encarnado na figura de Paranhos:

Este Gobierno sin opinión, sin prestijio y sin ningún tino para ejercer el mandato que le confiaron los Aliados, y un reducidísimo número de paraguayos, tiene sin embargo que venir al suelo, el primer día que se instale la Convención, ÚNICA AUTORIDAD LEJÍTIMA, DE ORIGEN POPULAR. Para entonces los enemigos del partido nacional, que ahora quiere combatir el que se ha conchabado ayer en el extranjero, por un buen salario, para venir a escribir aquí, sobre sucesos que no conoce más que por el metálico que guarda cada mes, entonces decimos han de ver aquellos su error, y tal vez se acuerden que son [ilegível] y que deben concurrir unidos á la felicidad de su país. (La Voz del Pueblo, Assunção, 19/07/1870).

Em abril de 1870, o periódico portenho La Tribuna deu publicidade ao debate que haviao corrido entre o redator de La Voz del Pueblo e um pseudônimo chamado Mucio Scevola. Este havia enviado o artigo "La Situación", cujo conteúdo se desconhece, ao redator do jornal assuncenho. Este, em sua resposta reproduzida pelo periódico argentino, destaca estar plenamente contrário às ideias de Scevola, pois:

Para nosotros, los aliados cometieron un error al consentir la instalación de un gobierno paraguayo, antes de terminarse la campaña contra Lopez, por que ese gobierno tenía que ser como fue, y no se tuvo la franqueza de decirlo. Se prometió instalar un gobierno emanado de la voluntad del pueblo, y luego que se vio la imposibilidad de consentir en esto, a causa de las exajeradas pretensiones de algunos se hizo lo que se debía haber hecho desde un principio, esto es, nombrar los aliados el gobierno del Paraguay. [...] No somos pues plagistas, y pensamos hoy como ayer teniendo la satisfacción de que muchos nos [ilegível], que el gobierno del Triunvirato fue un Gobierno impuesto por los aliados, como debió ser; y que los paraguayos no deben permitir a ese Gobierno más que la convocación de la convención constituyente, la que debe entonces nombrar su provisorio que nada tendrá que ver con el provisorio de los aliados, para que este dirija los trabajos que han de dar por resultado el gobierno efectivo de la Republica del Paraguay. (La Tribuna, Buenos Aires, 10/04/1870). 
Outro momento em que jornais portenhos deram espaço para artigos de $L a$ Voz havia sido em julho, quando El Nacional publicou o "Boletín de la "Voz del Pueblo"”, no qual reproduzia o texto titulado "Sospechas de revolución":

[...] Ahora ya no tienen que dudar los hijos del pueblo. El Gobierno Provisorio, es Gobierno Brasilero, y las tres mil bayonetas que tienen en la Asunción, cuatro ó cinco mil que se hallan en Humaita, y toda la armada en estación en el puerto, han de dirijir sus tiros al corazón de los hijos de la nación, en el primer momento que quieran manifestar la soberanía que les han prometido. [...] Viendose el Gobierno completamente perdido, y comprendiendo que el día de las elecciones, una manifestación completa en su contra, lo iba a arrancar de ese puesto que ocupa CONTRA LA DECIDIDA VOLUNTAD DEL PUEBLO, ocurrió al Sr. Consejero Paranhos quien le aseguro su protección, poniendo en el acto en movimiento todos los Batallones y los Rejimientos, con mas actividad que la que se hubiese imajinado. [...] El pueblo paraguayo ha sido pues conquistado, y de hoy en adelante la Redacción de "La Voz del Pueblo", defiende a los derechos del Pueblo, no ya usurpado por un Gobierno dictatorial, sino por un poder estraño que viene imprudentemente a comprometer una situación arrojando chispas sobre la Santa-Barbara.

"CLUB DEL PUEBLO". La Comisión Directiva del "Club del Pueblo" nos pide anunciemos en esta hoja suelta, que suspende el meeting á que había invitado para hoy a las 3 de la tarde, hasta nueva orden, en vista de la nueva situación creada por la imposición brasilera. (El Nacional, Buenos Aires, 07/07/1870).

Os redatores de La Tribuna, por sua vez, publicaram um texto crítico aos responsáveis por La Voz del Pueblo, pois estes teriam apoiado uma tentativa de revolução contra o governo paraguaio, a qual se viu frustrada diante do apoio e da proteção que lhe prometeram as autoridades aliadas no país:

[...] Esos informes nos han traído el conocimiento de que es cierto que una revolución debió estallar en la Asunción, y como según los convenios celebrados con el Gobierno Provisorio, las fuerzas arjentinas y brasileras están en el deber de prestarle su apoyo moral y material hasta tanto se organice el Gobierno [ilegível], arjentinos y brasileros procedieron con arreglo a esos convenios para adoptar las medidas que adoptaron, en los momentos en que una nueva revolución amenazaba ensangrentar de nuevo el Paraguay. [...] Más de una vez hemos atacado la política y la diplomacia brasilera. Pero el único timbre de que queremos hacer alarde es nuestra sincera imparcialidad, principalmente cuando se trata de aquellos a quienes hemos atacado. Como prenda de paz, como garantía de la futura tranquilidad del Paraguay, los aliados se han obligado a sostener al actual Gobierno Provisorio, porque él es la base indispensable de la organización de los poderes públicos en aquella República. ( $L a$ Tribuna, Buenos Aires, 09/07/1870). 
Assim como El Nacional, La Tribuna nutria antipatia pela política brasileira na Região do Rio da Prata desde os anos de guerra com o Paraguai, embora este último fosse menos ácido em seus ataques. Apesar desta postura, o jornal defendeu a atuação das forças aliadas em Assunção ao conter uma insurreição armada e criticou os exageros propagados por La Voz del Pueblo, ressaltando que as autoridades aliadas não fizeram nada mais que cumprir com o seu dever ao respaldar o Governo Provisório.

La Voz del Pueblo e La Tribuna voltaram a trocar críticas ainda em julho de 1870, após a oficina do jornal assuncenho ter sido atacado por soldados brasileiros irritados com textos considerados ofensivos. Este episódio, que ganhou considerável repercussão na imprensa platina, assim foi noticiado por Miguel Gallegos após já haver conseguido outra impressora para dar continuidade à circulação do jornal:

La tormenta que se descargó al fin en la noche del 15 del corriente, no la hemos provocado nosotros que no hemos hecho más que decir verdades; esa tormenta ha sido el resultado lójico de la impotencia de los que no teniendo razones que oponer a las nuestras, han querido matar la voz de la verdad, echando una imprenta a la calle, como si quince días después no habíamos de tener otra imprenta planteada, y otra vez la facilidad de denunciar los déspotas para que el mundo entero los maldijese cien veces más. [...] Porque hemos dicho que soldados brasileros atacan una casa con la idea de echar una imprenta a la calle; [...] Toda nuestra oposición es á la política del Consejero Paranhos, como seria a la del Ministro Argentino si lo viésemos influyendo en lo más mínimo en los asuntos locales del Gobierno Provisorio del Paraguay. (La Voz del Pueblo, Assunção, 19/07/1870).

José Segundo Decoud noticiou a destruição da impressora de La Voz del Pueblo e denunciou os atropelos cometidos pelos soldados brasileiros, todavia não perdeu a oportunidade de alfinetar:

Hemos desaprobado y desaprobamos hoy el atentado que ha sido cometido por algunos soldados brasileros contra un periódico y una familia paraguaya. Nadie tiene derecho a atentar contra la propiedad y la vida de un ciudadano. [...] Es verdad que los brasileros han procedido con poca reflexión, pero es también cierto que el único causante de su propio mal ha sido el periódico La Voz del Pueblo. De algún tiempo a esta parte su constante propaganda ha sido contra los brasileros, llegando hasta a calumniarlos muchas veces, con el objeto tal vez de cohonestar esa misma propaganda, cuando tuvo la infeliz idea de llevar al primer puesto de la República a un ex ministro del fallecido tirano y pariente del mismo. (La Regeneración, Assunção, 20/07/1870).

O portenho La Tribuna, por sua vez, assim respondia às críticas feitas por La Voz no seu primeiro número a circular após o ataque: 
La Voz del Pueblo, cuya imprenta fue atacada, al referir a los hechos pregunta: ¿Qué nos dirá de esto la TRIBUNA de Buenos Aires? La Tribuna de Buenos Aires, contestamos, dirá siempre la verdad, pese a quien pese, en este hecho como en cualquier otro... [...] No es un acto de las fuerzas brasileras, sino simplemente un delito vulgar, cometido por individuos que pertenecen a aquellas fuerzas. Al cometerlo no han obrado como soldados, bajo la bandera imperial, no obedeciendo órdenes de sus gefes superiores. Han obrado como hombres, y esto es lo que muestran las partes y documentos oficiales que al pié publicamos. (La Tribuna, Buenos Aires, 22/07/1870).

La Voz del Pueblo retornou a circular alguns dias após o ataque perpetrado por soldados brasileiros. No entanto, circulou somente até setembro, pois o estabelecimento onde funcionava foi novamente atacado por agentes desconhecidos (WHIGHAM, 2015).

No último dia de agosto, os deputados convencionais ligados ao decoudista Gran Club del Pueblo conseguiram declarar inválido o Triunvirato, destituir Cirilo Rivarola e eleger Facundo Machaín presidente provisório do Paraguai. No entanto, no dia seguinte, $1^{\circ}$ de setembro de 1870, Cirilo Rivarola, com o apoio do ex-opositor Cándido Bareiro e das autoridades aliadas, anulou as decisões do dia anterior, destituiu alguns deputados decoudistas dos seus cargos na Assembleia Constituinte e retornou ao poder, assumindo, desta vez, o posto de presidente provisório do país. Com este radical giro político, o até então situacionista Gran Club del Pueblo se tornou opositor e inúmeros dos seus membros foram destituídos dos cargos públicos que ocupavam, os quais foram entregues aos membros da facção de Cándido Bareiro, a partir de então situacionista.

Este episódio evidencia o oportunismo existente entre os membros de ambas as facções políticas assuncenhas. Enquanto não possuíam cargos no Governo Provisório e não usufruíam das benesses que o poder e a simpatia das autoridades aliadas conferiam, os bareiristas consideravam ilegítimo o Triunvirato instalado e criticavam a atuação das autoridades brasileiras no país. No entanto, a partir do dia $1^{\circ}$ de setembro, os bareiristas chegaram ao poder daquele mesmo governo antes condenado e, com a ajuda das autoridades aliadas, dentre elas, daquela que eles mais se esforçaram por criticar durante os meses de circulação de La Voz del Pueblo.

\section{Considerações finais}

Os meses que se seguiram à ocupação aliada de Assunção, a partir de janeiro de 1869, e que antecederam a aprovação da primeira Constituição paraguaia, em novembro de 1870, estiveram marcados pela instabilidade política e a desorganização social. Inúmeros cidadãos 
paraguaios se apresentaram para contribuir na reconstrução do país, contudo o faccionalismo e o personalismo que caracterizaram as duas agrupações políticas surgidas com o final do conflito tornaram a árdua tarefa de recuperação ainda mais difícil.

Club del Pueblo (ex-ClubUnión) e Gran Club del Pueblo, bareiristas e decoudistas foram protagonistas da nascente imprensa privada no Paraguai. Seus jornais, La Voz del Pueblo e La Regeneración, os primeiros jornais independentes surgidos no país, circularam durante meses conturbados e acabaram sendo vítimas do estado de insegurança e instabilidade que se vivia.

Enquanto La Regeneración representava o clube político situacionista, que ocupava cargos no governo; La Voz del Pueblo atuou como um jornal oposicionista por grande parte dos meses em que circulou. Fazia oposição ao Gran Club, condenava a ilegitimidade do Governo Provisório instalado e criticava tenazmente a atuação brasileira no Paraguai, embora tenha assumido cargos no criticado Governo Provisório e com o apoio das mesmas autoridades aliadas. Personalismo, faccionalismo e oportunismos à parte, La Voz del Pueblo contribuiu, junto com o opositor La Regeneración, para inaugurar a prática de debates públicos por meio da imprensa em um país onde ainda não havia existido liberdade de expressão.

\section{Fontes}

El Nacional - Hemeroteca da Biblioteca do Congresso Nacional da Argentina.

El Paraguay - Biblioteca Nacional do Paraguai.

La Tribuna - Hemeroteca da Biblioteca do Congresso Nacional da Argentina.

La Regeneración - Biblioteca Nacional do Paraguai.

La Voz del Pueblo - Instituto Histórico-Geográfico do Rio Grande do Sul.

\section{Referências}

ACOSta TOLEDO, Gustavo Alfredo. Posguerra contra la Triple Alianza. Aspectos Políticos e Institucionales (1870-1904). Asunción: Servilibro, 2013.

ALONSO, Paula. Introducción. In: ALONSO, Paula (Org.). Construcciones Impresas: Panfletos, diarios y revistas en la formación de los Estados nacionales en América Latina, 1820-1920. Buenos Aires: FCE, 2004, p. 7-12.

ARECES, Nidia. De la Independencia a la Guerra de la Triple Alianza (1811-1870). In: TELESCA, Ignacio (Org.) Historia del Paraguay. Asunción: Prisa Ediciones, 2011.

BARATTA, María Victoria. ¿Aliados o enemigos? Las representaciones de Brasil en el debate público argentino durante la Guerra del Paraguay (1864-1870). Revista de História, São Paulo, n. 172, p. 1-34, jan./jun. 2015. 
. El Litoral y la batalla de pluma: la identidad nacional argentina en los periódicos de Entre Ríos y Corrientes durante la Guerra del Paraguay (1864-1870). Folia Histórica del Nordeste, Resistencia, n. 21, p. 75-96, 2013.

La oposición a la Guerra del Paraguay en Buenos Aires. Un análisis de las representaciones de la nación argentina en el periódico La América (1866). Revista Eletrônica da ANPHLAC, São Paulo, n. 13, p. 83-108, jul./dez. 2012.

BARBOSA, Marialva. História cultural da imprensa: Brasil, 1800-1900. Rio de Janeiro: Mauad X, 2010.

BREZZO, Liliana. Reconstrucción, poder político y revoluciones (1870-1920). In: TELESCA, Ignacio (Org.) Historia del Paraguay. Asunción: Prisa Ediciones, 2011. p. 199224.

; FIGALLO, Beatriz. La Argentina y el Paraguay, de la guerra a la integración. Imagen histórica y relaciones internacionales. Rosario: Instituto de Historia/Facultad de Derecho y Ciencias Sociales de Rosario/PUCA, 1999.

CRICHIGNO, Juan. Diarios del Paraguay. Asunción: ABC, Centro Gráfico, 2010.

DARNTON, Robert. O beijo de Lamourette. Mídia, Cultura e Revolução. São Paulo: Companhia das Letras, 1990.

DE MARCO, Miguel Angel. Historia del Periodismo Argentino: desde los orígenes hasta el Centenario de Mayo. Buenos Aires: Educa, 2006.

DORATIOTO, Francisco Monteoliva. A ocupação político-militar brasileira do Paraguai (1869-1876). In: CASTRO, Celso; IZECKSOHN, Vitor; KRAAY, Hendrik (Orgs.). Nova História Militar Brasileira. Rio de Janeiro: Editora FGV, 2004.

De aliados a rivais: o fracasso da primeira cooperação entre Brasil e Argentina (1865-1876)”. Revista Múltipla, Brasília, v. 4, p. 21-40, 1999.

Letras, 2002.

Maldita Guerra: Nova história da Guerra do Paraguai. São Paulo: Companhia das O Brasil no Rio da Prata (1822-1994). Brasília: FUNAG, 2014.

ESCOBAR, Ticio. A gravura popular, outra imagem da guerra. In: Maria M. Marques (Org.). A guerra do Paraguai: 130 anos depois. Rio de Janeiro: Delume-Dumará, 1995. P.121-129.

ESTEVES, Gomes. Historia Contemporánea del Paraguay.Asunción: El Lector, 1996.

GINZBURG, Carlo. Mitos, emblemas, sinais: morfologia e história. São Paulo: Companhia das Letras, 2012. 
HAVELOCK, Eric. A equação oralidade-cultura escrita: uma fórmula para a mente moderna. In: OLSON, David; TORRANCE, Nancy. (Org.) Cultura escrita e oralidade. São Paulo: Ática, 1995.

MONIZ BANDEIRA, Luiz Alberto. A expansão do Brasil e a formação dos estados na Bacia do Prata: Argentina, Uruguai e Paraguai (da colonização à Guerra da Tríplice Aliança). Rio de Janeiro: Civilização Brasileira, 2012.

PUSINERI, Adelina. Las luchas político-democráticas a través de la prensa y la Convención Nacional Constituyente de 1870.Diálogos. Maringá, v. 9, n. 2, p. 37-65, 2005.

RÉMOND, René (Org.). Por uma história política. Rio de Janeiro: FGV, 2003.

ROLÓN, Oscar Bogado. Sobre Cenizas: Construcción de la Segunda República del Paraguay - 1869/1870. Asunción: Editora Intercontinental, 2011.

WARREN, Harris Gaylord. Paraguay y la Triple Alianza. La Década de Posguerra: 18691878. Asunción: Intercontinental, 2009.

WASSERMAN, Fabio. La libertad de imprenta y sus límites: prensa y poder político en el Estado de Buenos Aires durante la década de 1850. Revista Almanack Braziliense, São Paulo, n. 10, p. 130-146, nov. 2009.

Prensa, debates y vida pública en Buenos Aires durante la década de 1850. In: XIV Jornadas Interescuelas/Departamentos de Historia, 2013. Universidad Nacional de Cuyo, Mendoza. p. 1-17.

WHIGHAM, Thomas. La Guerra de la Triple Alianza. Danza de muerte y destrucción. Asunción: Taurus, 2012. Volumen III.

Silva Paranhos e as origens de um Paraguai Pós-López (1869). Dialogos (Maringá Online), v. 19, n. 3, p. 1085-1119, set.-dez./2015. 